Journal of Extension Education

Vol. 29 No. 2, 2017

DOI:https: / / doi.org/10.26725/JEE.2017.2.29.5831-5837

\title{
Gender Disparity in Access to Information and Extension Services in Dairy Farming
}

\author{
Maneesha Bhuyan ${ }^{1 *}$ and K. Ponnusamy ${ }^{2}$
}

\begin{abstract}
A study on the role of men and women in accessing different communication sources and extension services in dairy farming was undertaken during 2016-17 in Haryana, India with 120 randomly selected women farmers. Personal interview and PRA (Participatory Rural Appraisal) methods were used for data collection and analyzed using frequency and percentage. Majority of males had land ownership, livestock and credit. Majority of the women respondents had occasional contact with veterinary surgeons \& ICAR-National Dairy Research Institute and animal feed dealers. However in case of informal sources, majority of the males had contact with relatives/ friends. Women's role is highly reflected in fodder collection, feed preparation, cleaning of animal shed, milking and taking care of animals. This gender disparity brings urgent need to sensitize the dairy farmers/farm women and enable them to have equal access of resources, input and opportunities through appropriately designed extension models for ultimate empowerment of farm women and the progress of the country.
\end{abstract}

Keywords: Dairy farming; gender role; extension services; women empowerment; gender disparity

\section{INTRODUCTION}

Women are integral part of dairying and nearly 70 per cent of them are involved in various activities. Dairy enterprise has been regarded as an important socio economic instrument to supplement the income and employment to the women (Ponnusamy et al., 2017). Women generally contribute more labour inputs in the areas of fodder cutting, watering, cleaning of animals cattle sheds etc (Arshad et al., 2013). The possession of cattle is also increasing with landless farmers where women play a pivotal role in ensuring food and nutritional security. Although more than 70 per cent of dairying activities are being carried out by women, there is a limited level of ownership of animals. Although much of women labour work is non-monetized, they often decide the amount of milk to be sold and how to use the revenues generated from milk sales. Women don't have much role in marketing of milk and milk products, purchase and disposal of dairy animals and investment

1. PhD Scholar \& 2. Principal Scientist, Dairy Extension Division, ICAR-NDRI, Karnal-132001, India 
in animal shelter, equipments and machineries (Ponnusamy, 2006). The role and contribution of women in dairying other than usual household responsibilities had been interpreted in economical pretext (Upadhyay et al., 2007). Further, few women had access to ownership of livestock and they do not have any access to extension or veterinary services. Evidence from the study on role-responsibilities, access and control over the resources would help in understanding the socio-economic status of gender in general and women in particular in the study area.

\section{METHODOLOGY}

The study was carried out in two villages namely Pingli and Jundla of Karnal district in Haryana during 201617. Altogether, 120 farm women were randomly selected, 60 each from Pingli and Jundla villages. Respondents were chosen from landless, marginal, small and large categories based on simple random sampling. Data were collected by well structured and pretested interview schedule apart from Participatory Rural Appraisal (PRA) methods. Data were analyzed for descriptive statistics (i.e. Percentages, frequencies) using Statistical Package for Social Sciences (SPSS) Version 16.

\section{FINDINGS AND DISCUSSION}

The role of gender in dairy farming indicated that both men and women were involved in various dairy activities. However female participation was found maximum in dairy activities such as collection of fodder $(75.8 \%)$, cleaning of cattle shed (92.5\%), feed preparation $(83.3 \%)$, milking and processing of milk $(92.5 \%)$ and taking care of animal during pregnancy (90\%) in both the villages. Farm women did not participate in marketing of animals (cows / buffaloes / calves). Few women respondents (19.2\%) were engaged in marketing of milk.

The access to resources by male, female or by both is shown in Table 1 . The results revealed that in Pingli access and ownership of resources such as land property, livestock, credit, implement, machinery and investment belonged to male members of respondent's family, which accounts for 88.30, 71.70, 90.00, 78.30, 90.00 and 81.70 per cent, respectively and in Jundla 88.30, 70.00, $85.00,83.30,86.70$ and 83.30 per cent, respectively. During investigation it was found that majority of families in Jundla and a few families in Pingli belonged to landless group. Hence, the landless respondents did not have much access to land property. It was also observed that among remaining respondent's families in both the villages who owned land, few respondents had the legal title of land in their name. Few per cent of women had legal title of land due to death of husband or divorce. Government of Haryana is also encouraging the farm families to register property in female in order to avail concessional stamp duty. It was found that, the income obtained from sale of milk was utilized by 53.3 per cent male in Pingli and 60 per cent male in Jundla. 
Table 1.

Access of Men and Women to Resources in Dairy Farming

\begin{tabular}{|c|c|c|c|c|c|}
\hline $\begin{array}{l}\text { S1. } \\
\text { No. }\end{array}$ & Resources & Category & $\begin{array}{c}\text { Pingli } \\
(\mathrm{n}=60)\end{array}$ & $\begin{array}{c}\text { Jundla } \\
(\mathrm{n}=60)\end{array}$ & $\begin{array}{c}\text { Total } \\
(n=120)\end{array}$ \\
\hline 1. & Land property & \begin{tabular}{|l|} 
Men \\
Women \\
Both
\end{tabular} & $\begin{array}{l}53(88.3) \\
5(8.3) \\
2(3.3)\end{array}$ & $\begin{array}{l}53(88.3) \\
4(6.7) \\
3(5)\end{array}$ & $\begin{array}{l}106(88.3) \\
9(7.5) \\
5(4.2)\end{array}$ \\
\hline 2. & Livestock & $\begin{array}{l}\text { Men } \\
\text { Women } \\
\text { Both }\end{array}$ & $\begin{array}{l}43(71.7) \\
6(10.0) \\
11(18.3)\end{array}$ & $\begin{array}{l}42(70.0) \\
4(6.7) \\
14(23.3)\end{array}$ & \begin{tabular}{|l}
$85(70.8)$ \\
$10(8.3)$ \\
$25(20.8)$
\end{tabular} \\
\hline 3. & Credit & $\begin{array}{l}\text { Men } \\
\text { Women } \\
\text { Both }\end{array}$ & $\begin{array}{l}54(90.0) \\
3(5.0) \\
3(5.0)\end{array}$ & $\begin{array}{l}51(85.0) \\
5(8.3) \\
4(6.7)\end{array}$ & $\begin{array}{l}105(87.5) \\
8(6.7) \\
7(5.8)\end{array}$ \\
\hline 4. & Implement & $\begin{array}{l}\text { Men } \\
\text { Women } \\
\text { Both }\end{array}$ & $\begin{array}{l}47(78.3) \\
7(11.7) \\
6(10.0)\end{array}$ & $\begin{array}{l}50(83.3) \\
4(6.7) \\
6(10.0)\end{array}$ & $\begin{array}{l}97(80.8) \\
11(9.2) \\
12(10.0)\end{array}$ \\
\hline 5. & Machinery & $\begin{array}{l}\text { Men } \\
\text { Women } \\
\text { Both }\end{array}$ & $\begin{array}{l}54(90.0) \\
3(5.0) \\
3(5.0)\end{array}$ & $\begin{array}{l}52(86.7) \\
2(3.3) \\
6(10.0)\end{array}$ & $\begin{array}{l}106(88.3) \\
5(4.2) \\
9(7.5)\end{array}$ \\
\hline 6. & Investment & $\begin{array}{l}\text { Men } \\
\text { Women } \\
\text { Both }\end{array}$ & $\begin{array}{l}49(81.7) \\
7(11.7) \\
4(6.7)\end{array}$ & $\begin{array}{l}50(83.3) \\
8(13.3) \\
2(3.3)\end{array}$ & $\begin{array}{l}99(82.5) \\
15(12.5) \\
6(5.0)\end{array}$ \\
\hline 7. & $\begin{array}{l}\text { Income from } \\
\text { sale of milk }\end{array}$ & \begin{tabular}{|l} 
Men \\
Women \\
Both
\end{tabular} & $\begin{array}{l}32(53.3) \\
17(28.3) \\
11(18.3) \\
\end{array}$ & $\begin{array}{ll}36 & (60.0) \\
14 & (23.3) \\
10 & (16.7)\end{array}$ & $\begin{array}{ll}68 & (56.7) \\
31 & (25.8) \\
21 & (17.5)\end{array}$ \\
\hline
\end{tabular}

(Figures in parentheses depict the percentage to total)

About one- sixth (18.3\% in Pingli and $16.7 \%$ in Jundla) were jointly utilizing the income derived from sale of milk. Hence, it is concluded that as per access to resources are concerned, in both the villages, men were having dominant share over women.

Data in Table 2 reveal that, in
Pingli, men were accessing variety of information sources. About 81.7 per cent of respondents revealed that men were taking advice or information about dairy or about any government scheme from their friends/ relatives. Only 18.3 per cent women respondents utilized friends and relatives. Brokers and commission 
agents were utilized by 91.7 per cent of men and only 8.3 per cent women utilized them. Eighty five per cent men utilized local newspaper as compared to 15 per cent of women. Television was used by
86.7 per cent of men against 13.3 per cent by female for getting information on agriculture and related information. Community leaders were utilized by 93.3 per cent men.

Table 2

Access to Extension Services from Informal Sources regarding Dairy Farming

\begin{tabular}{|c|c|c|c|c|c|}
\hline $\begin{array}{l}\text { S1. } \\
\text { No. }\end{array}$ & Particulars & Category & Pingli & Jundla & Total \\
\hline 1. & $\begin{array}{l}\text { Relatives, } \\
\text { friends, } \\
\text { neighbours }\end{array}$ & $\begin{array}{c}\text { Men } \\
\text { Women }\end{array}$ & $\begin{array}{l}49(81.7) \\
11(18.3)\end{array}$ & $\begin{array}{l}45(75.0) \\
15(25.0)\end{array}$ & $\begin{array}{l}94(78.3) \\
26(21.7)\end{array}$ \\
\hline 2. & $\begin{array}{l}\text { Brokers and } \\
\text { commission } \\
\text { agents }\end{array}$ & $\begin{array}{c}\text { Men } \\
\text { Women }\end{array}$ & $\begin{array}{c}55(91.7) \\
5(8.3)\end{array}$ & $\begin{array}{c}53(88.3) \\
7(11.7)\end{array}$ & $\begin{array}{c}108(90.0) \\
12(10.0)\end{array}$ \\
\hline 3. & $\begin{array}{l}\text { Local } \\
\text { newspaper }\end{array}$ & $\begin{array}{c}\text { Men } \\
\text { Women }\end{array}$ & $\begin{array}{c}51(85.0) \\
9(15.0)\end{array}$ & $\begin{array}{c}56(93.3) \\
4(6.7) \\
\end{array}$ & $\begin{array}{c}107(89.2) \\
13(10.8) \\
\end{array}$ \\
\hline 4. & Television & $\begin{array}{c}\text { Men } \\
\text { Women }\end{array}$ & $\begin{array}{c}52(86.7) \\
8(13.3)\end{array}$ & $\begin{array}{l}50(83.3) \\
10(16.7)\end{array}$ & $\begin{array}{c}102(85.0) \\
18(15.0)\end{array}$ \\
\hline 5. & $\begin{array}{l}\text { Community } \\
\text { leaders }\end{array}$ & $\begin{array}{c}\text { Men } \\
\text { Women }\end{array}$ & $\begin{array}{c}56(93.3) \\
4(6.7)\end{array}$ & $\begin{array}{c}52(86.7) \\
8(13.3)\end{array}$ & $\begin{array}{c}108(90.0) \\
12(10.0)\end{array}$ \\
\hline 6. & NGO & $\begin{array}{c}\text { Men } \\
\text { Women }\end{array}$ & $\begin{array}{l}0(.0) \\
0(.0)\end{array}$ & $\begin{array}{c}53(88.3) \\
7(11.7)\end{array}$ & $\begin{array}{c}53(44.2) \\
7(5.8)\end{array}$ \\
\hline
\end{tabular}

(Figures in parentheses depecit the percentage to total)

While 75 per cent men were depending on friends and relatives to know about dairy related information or about any government scheme, 88.3 per cent of them utilized brokers and commission agents as their source of information. Local newspapers were utilized by 93.3 per cent of men and 6.7 per cent women utilized the same while television was used by 83.3 percent of male. Regarding community leaders, 86.7 per cent of male utilized them. During investigation it was found that NGOs such as "Jan Kalyan Samiti" help the women in organising SHG, arranging bank loans and other capacity building activities.

Respondents were requested to reveal the various extension agents who were visiting their village and their frequency of visit. The responses were recorded and the results are presented in Table 3. 
Gender Disparity in Access to Information and Extension Services in Dairy Farming

Table 3.

Access to Extension Services from Formal sources regarding Dairy Farming

\begin{tabular}{|c|c|c|c|c|c|}
\hline $\begin{array}{l}\text { S1. } \\
\text { No. }\end{array}$ & $\begin{array}{l}\text { Extension } \\
\text { agent }\end{array}$ & $\begin{array}{c}\text { Frequency of } \\
\text { contact }\end{array}$ & Pingli $(n=60)$ & $\begin{array}{l}\text { Jundla } \\
(n=60)\end{array}$ & $\begin{array}{l}\text { Pooled } \\
(n=120)\end{array}$ \\
\hline 1. & $\begin{array}{l}\text { Village level } \\
\text { extension } \\
\text { worker }\end{array}$ & Never & $60(100)$ & $60(100)$ & 120 (100) \\
\hline 2. & $\begin{array}{l}\text { Agricultural } \\
\text { extension } \\
\text { officer }\end{array}$ & Never & $60(100)$ & $60(100)$ & $120(100)$ \\
\hline \multirow{3}{*}{3.} & \multirow{3}{*}{$\begin{array}{l}\text { University / } \\
\text { Institute } \\
\text { personnel }\end{array}$} & Regular & 8 (13.3) & $0(0.0)$ & $8(6.7)$ \\
\hline & & Occasional & $47(78.4)$ & $0(0.0)$ & $47(39.2)$ \\
\hline & & Never & $5(8.3)$ & $60(100)$ & $65(54.1)$ \\
\hline \multirow{2}{*}{4.} & \multirow{2}{*}{$\begin{array}{l}\text { Veterinary } \\
\text { assistant } \\
\text { surgeon }\end{array}$} & Regular & $13(21.7)$ & $22(36.7)$ & 35 (29.8) \\
\hline & & Occasional & 47 (78.3) & $38(63.3)$ & $85(78.2)$ \\
\hline \multirow{4}{*}{5.} & $\begin{array}{l}\text { Para } \\
\text { veterinarian }\end{array}$ & Occasional & $60(100)$ & $60(100)$ & $120(100)$ \\
\hline & \multirow{3}{*}{ NGO personnel } & Regular & $0(0.0)$ & 7 (11.7) & $7(5.8)$ \\
\hline & & Occasional & $0(0.0)$ & $14(23.3)$ & $14(11.7)$ \\
\hline & & Never & $60(100)$ & $39(65.0)$ & 99 (82.5) \\
\hline \multirow{2}{*}{6.} & \multirow{2}{*}{$\begin{array}{l}\text { Veterinary } \\
\text { feed dealer }\end{array}$} & Occasional & 27 (45.0) & $0(0.0)$ & 27 (22.5) \\
\hline & & Never & $33(55.0)$ & $60(100)$ & $93(77.5)$ \\
\hline
\end{tabular}

(Figures in parentheses depict the percentage to total) 
100 per cent of the respondents in both the villages did not have any contact with village level extension workers and agricultural extension officers. Majority of respondents in Pingli i.e. 78.4 per cent had occasional contact with university/ institute personnel followed by regular contact i.e. 13.3 per cent whereas, in Jundla none of the respondents had any contact with this extension agencies. Majority of respondents in Pingli (78.3\%) as well as in Jundla (63.3\%) had occasional contact with the veterinary surgeon followed by regular contact i.e. 21.7 per cent and 36.7 per cent respondents respectively. Hundred per cent of respondents had occasional contact with para veterinarians. In Jundla, 23.3 per cent of respondents had occasional contact with NGO personnel whereas, 11.7 per cent of respondents had regular contact with them. But there is no presence of NGO in Pingli. It was also found that 45 per cent of respondents in Pingli had occasional contact with animal feed dealers.

\section{CONCLUSION}

The gender issues vis a vis their communication sources in dairy farming as found across the country are also prevalent in the villages typically reflecting the patriarchal nature of society which could be gradually addressed as per the strategic gender needs (SGN) and practical gender needs (PGN). This includes access to education, community participation, decision making in the family and control over income of the family. Special efforts are required to address the genuine concerns of female headed farm families which comprise around 10 per cent of respondents in the project villages. Access to training and critical farm inputs is the major requirements of these families. In view of very low utilization of formal information sources such as extension functionaries of agricultural and animal husbandry departments, ATMA and NABARD should extend group approaches such as commodity groups and farmer clubs in order to push the technology transfer for sustainable farming. While men dominated information seeking behaviour from variety of sources, women restrict themselves to seek information from family members, which needs to be looked into.

\section{REFERENCES}

Arshad, S., Muhammad, S \& Ashraf, I. (2013). Women's participation in livestock farming activities. The Journal of Animal \& Plant Sciences, 23 (1), 304-308.

Jayakumar, N \& Surudhi, M. (2015). Gender equality in Agricultural Extension. Journal of Extension Education, 27(1), 5381 - 5391.

Ponnusamy, K. (2006). Multidimensional analysis of integrated farming system in the coastal o system of Tamil Nadu. Unpublished Ph.D. Thesis. Karnal, ICAR-NDRI 
Ponnusamy, K., Chauhan, A. K \& Meena, S. (2017). Testing the effectiveness of Pasu Sakhi: An innovation for resource poor farm women in Rajasthan. Indian Journal of Animal Sciences, 87 (2), 229-233.
Upadhayay, M \& Intodia, S. L. (2007). Involvement of women dairy cooperative society members in decision making process. Rajasthan Journal of Extension Education, 15, 97-101. 